\title{
Factors Influencing the Career Decision Making Process in Secondary School in Vietnam
}

\author{
Do Thi Bich Loan, Nguyen Thuy Van, Nguyen Duc Trung
}

\begin{abstract}
The purpose of this study is to reveal the stages of career decision making process and emphasizes the influencing factors in each period of secondary students at the time of enrollment in Vocational and Technical Education Institutes (VTE). The analysis of documents reveals that career decision making process consists of four stages: (1) needs identification; (2) information search; (3) evaluation of alternatives; and (4) choices. Different factors impact each stage, such as personal interest, expectations \& ability (self-motivated, academic performance; self-efficacy); family context (incomelfinance, geographical location, experiences); Schools' career ready (career counselor's orientation, teacher's recommendation, career aspirations); professional educational system (quality of VTE training and employments; career transition); social - economic (study fees, career prospects, career value; national trend of labor market; and the mass media). This study suggests that the above factors play a crucial role in designing suitable policies and career ready program for secondary students in the Vietnamese context.
\end{abstract}

Key words: career decision-making, Vietnamese secondary students

\section{INTRODUCTION}

In Vietnam, the national education system has four subsystems; the Pre- school education which includes kindergarten for children 3 to 6 years old, the 5-4-3 system for primary (grade 1 to 5), secondary (grade 6 to 9) and high school (grade 9 to 12) (MOET, 2007). As for other Asian countries, such as South Korea, Indonesia, and Malaysia, they maintain separate systems for Vocational and Technical Education (VTE) and the academic schools (higher education) for school leavers (Metheny \& Mcwhirter, 2013)

Vocational and Technical Education (VTE) consist of two sub-systems: vocational schools and centers specialized in training skilled or semi-skilled workers; and the technical vocational school specialized in training intermediate practitioners in the field of education, economy, technology, culture and art (La, 2009). Although the Ministry of

Revised Manuscript Received on September 22, 2019.

Do Thi Bich Loan, Ph.D., Associate Professor, senior researcher in Vietnam National Institute of Educational, Hanoi, Vietnam

Nguyen Thuy Van, PhD. Social Science \& Humanities Faculty, Universiti Teknologi Malaysia, Johor, Malaysia.

Nguyen Duc Trung, Researcher in The Institute for Research and Design of School, Vietnam Ministry of Education and Training, Hanoi, Vietnam.
Education and Training (MOET) largely supervises vocational and technical education's curriculum and programs, it plays a small role in VTE provision, running only 4 out of the 91 centrally-managed secondary technical schools (Tri, 1994).

In fact, there is a popular phenomenon in vocational behavior in Vietnam with most of students in favor of traditional university while a less number leave school and enroll at/in vocational and technical colleges. According to the Ministry of Education and Training (2017), the findings of investigation of a Project, "Career-oriented education and orientation of high school students" showed that postsecondary students studying at high school accounted for 79.6\%; school center around 5.6\%; enroll in vocational and technical education $7.8 \%$; go to work $4.6 \%$.

The rate of postsecondary students in making their choice of career has led to an imbalance in the structure of training and preparing labor force for human resources in national social economic development in Vietnam. In 2016, the national data survey center of workers Employment indicated that there were 1,110,000 unemployed people, among them the highest number were of them who had bachelor degrees, accounted for 218,800 people (46.4\%); diploma college degree, accounted for 124,800 people ( $26.5 \%$;) due to which, there arises a shortage of skilled workers in industries and factories. The existing statistic indicates that many of university and college graduates do not have jobs. This is because these institutions produce unskilled workers, which the Vietnamese call "many teachers, and less workers". This serious problem calls for serious attention and consideration in order to improve the quality of vocational and technical education system as well as the career advising in secondary schools. This paper tries to review the career decision making process and factors of career choice and engagement in career readiness with the hope to contribute to the literate review of vocational and technical education in Vietnam.

\section{CAREER DECISION MAKING PROCESS}

Several studies related to career decision making process assumed that this procedure is a complex and multi-phase process (Mihai-Florin, Dorel \& Alexandra-Maria, 2006; Harris \& Taylor, 2004; Eidimtas \& Juceviciene, 2014, Andrius \&Palmira, 2003). Some researchers present their studies with the conclusion of school-leavers` choice of 
studies based on classic models of a consumer's decision-making (Chimanikire, Mut, Gadzirayi, Muzondo, \& Mut, 2007; Briggs \& Wilson, 2007).

According to Bruyat \& Julien (2001) career making decision process seems to be for individual development. Entrepreneurship has been defined as a process of exploration, searching information and evaluation as well as exploitation of opportunities through which individuals seek to create value by involving their interest and ability to get a nexus of opportunities and persons' development Shane \& Venkataraman (2000). However, every person is constantly affected by a complex totality of social relations. Reviews showed that various fields of science (psychology, sociology, economics), investigated and emphasized the relationship between the school-leaver views and investment into the labor market in the future. How the society and environment impact their decision to leave schools and opt for other careers (Andrius \& Palmira, 2013). For example, Shaver \& Scott (1992) indicated that individual behavior of social cognitive processes has an impact on building representations of their external environment, and the motivational variables that affect behavioral choices.

Notably, Lent, Brown, and Hackett (1994, 2000), developed their social cognitive career theory (SCCT), in which authors illustrate how career choice, interest, performance, and satisfaction develop in an ongoing cycle (Brown \& Lent, 2013). Reviews indicated that one single measurement for college and career choice making of school leavers is insufficient and limited, because this process is complicated and the influencing factors are multi circles (Dalton, 2018). Self-efficacy and outcome expectations are significantly influencing the performance of setting goals (Dalton, 2018). Contextual variables such as, ability and disability, ethnicity, gender and socioeconomic status influence learning experiences and interests, choices of goals, and choice of actions are moderate constructs (Brown \& Lent, 2013). Dalton (2018) emphasized that the previous literature promotes exposure to career development, the SCCT models provide a framework which intentionally plans career development interventions, currently applied to career choice making procedure for career ready high school graduates. The SCCT has attracted research interest with respect to entrepreneurial career (Lanero, Vázquez, \& Aza, 2016; Liguori et al., 2018). In sum up, this paper aims to review factors influencing career making decision process in the four stages: (1) needs identification, (2) information search, (3) evaluation of alternatives, and 4) choices. In each different stages, there are different factors affecting the complex correlation to impact the final decision (Andrius \& Palmira, 2013; Taylor, Harris \& Taylor, 2004; Hossler and Galagher, 1998).

\section{FACTORS INFLUENCING THE CHOICE OF CAREER}

\section{A. The Need of Identification}

Cosser and Du Toit (2002) state that students needs identification, their choices of career at the ninth grade and ends with the student signing a contract for enrolling in a certain higher education institution. At this stage, students at secondary school realize that the secondary education is not sufficient and university education or vocational education is required for career purposes in life (Pope \& Fermin, 2003). Moogan and Baron (2003) emphasize that needs recognition takes place in the initial stage of any decision making process and plays an important role in various internal or external factors (Al-Fattal, 2010; Andrius \& Palmira, 2013). The needs are usually determined by personal, cultural circumstances, as well as family and environment conditions (Hossler et al. ,1998; Moogan and Baron, 2003; Pérez \& Ceja, 2010, Al-Yousef, 2009; Wong and Liu, 2010). As a teenager, student usually tries to choose persons who are successful models to motivate them. Therefore, the career counselor in secondary school should help students to have enough information related to personal interest, family context, and overview of status of socio -economic of the country and the local areas as well as the trend of labor market for students to identify themselves for school-leaver with career ready.

The attitudes and opinions of a person formed by family environment condition influence the school-leaver's decision to enter higher school or vocational education. Pérez \& Ceja (2010) stated that the family status, elder siblings and school experience is a significant influence on the student career decision. Parental discussions in the families encourage pupils to pursue higher level or choose vocational education so as to find job early.

Secondary schools play an important role for career ready to support students. Bottoms (2004) stated that secondary school must be able to link their curricula to realistic and available professional opportunities. He further says that secondary school should incorporate career and postsecondary training and planning to find more success in preventing students' drop out. The current review proposes that schools can mitigate students' potential barriers to career achievement with career development resources and support for all students (Praskova, Creed, \& Hood, 2015).

In Vietnam, with the emergence of new jobs in various fields has caused an enormous change in the perspectives of parents towards career choices for their children. This emergence of new jobs also transformed the choices of their children. However, many parents and senior family members still play important roles in guiding their children in career decision-making process (Khuat, 1992; Ngo, 2005). The review indicates that in the decade of eighties, when the economy of Vietnam was still under-developed by the negative impact of war, 
parents used to be non-farmers, living in urban, wanted their children to continue their study in high school and enroll in higher education. However, parents who were farmers could not have their children complete their high school because of low income and unclear expectations about their children's career. In that case, they usually left their children to decide on their own. Thus, most of them already studying in the vocational technique schools and decided to learn handwork careers in village so that they may get stable job to support their family (Khuat, 1992).

However, currently, there has been an enormous change in the national economic development due to the open policies of the government at the end of twentieth century in Vietnam. La (2009) found that most of the families wanted their children to finish high school and have the opportunity of studying at universities. Furthermore, some of the respondents in their study emphasized their preference for high social status rather than menial work or hand maker irrespective of monetary benefits. This resulted in the imbalance of educational levels in Vietnam with regard to the great number of students opting for vocational and technical education. She emphasized the need for providing information about the value of vocational and technical education to both parents and children. However, in the Vietnamese current context, the result of a huge number of postsecondary students enroll in higher education and less number of students choose technically vocational education (institutes). The reason of this phenomenon may come from the poor career ready program in secondary school (Dalton, 2018). School leavers' decision may be determined by their traditional approach and less pay attention to the cognitive of career the social economic in the current practice. In the another hand, income and social position also affect students' career making decision process (La, 2009).

\section{B. Information Search}

In this stage, the pupils start considering various possibilities of studies at higher education (HE) institutions or vocational technique schools (Cosser and Du Toit, 2002). The searching stage starts with gathering of necessary information and assimilation by making a list of options based on various factors. Notably, school-leavers solely imagine the change of direction when collecting new information, the change of direction depends on the nature of new information obtained (Taylor, Harris \& Taylor, 2004).

There are two types of information search process: internal and external search (Barber, Dodd, and Kolyesnikova, 2009). When the internal search takes place, the user tries to retrieve information from his long term memory, the search from the external field of a current period has a strong impact on students. Whiteside \& Mentz (2003) stated if students have experiences of internal search from his or her own memories they can easily make their final decision of choice of career. With students lack internal search for their choice of career may have much information from external search, are usually unable to distinguish the useful information. The external search usually comes from various sources, such as personal sources, friends, family, relatives, career planning counselors, reference groups and public opinion leaders or independent sources of user groups, governmental institutions and mass media (Strauss, 1998; Rowan-Kenyon, Perna \& Swan, 2011, Al-Yousef, 2009)

In Vietnam, children have the tendency to find information related to social values and connections among education, occupation and income. (McMahon \& Watson, 2005, p. 243). The findings of this research show that the Vietnamese senior high school students are not only concerned about the status of career but also about their income. The students expressed that they wanted a stable, high income job, with a higher social status. "Social norms" such as what is considered to be a career, and what is not, and what is meant to be successful or unsuccessful, what is a noble job, and what is ignoble job. Besides, factors like gender, age, beliefs, ethnicity also contribute to a person's decision about his/her career (Ngo, p.2005). The above mentioned factors are the main reasons that a small number of students chose vocational training, while majority wanted to pursue general higher (academic or professional) education.

Another notable reason which positively affects students' academic and occupational choices is their living in urban areas in comparison to students who live in rural areas have less opportunities in occupational and academic world (La, 2009). In Vietnam, students living in rural have limited resources and limited access to information. For example, they do not have access to computers or printed media and most of them mainly learn about educational and career opportunities from their schools and peers. Students face difficulty in making decision regarding their choice of career based on the large information obtained from various sources and marketing promotion attracting the students. In Vietnam, the lack of career counselors at secondary school is one of main reasons to lead of the weak facilitates students in making decision regarding choice of career. It is one of reasons, students facing difficulty when make decision in a big data from various sources in the marketing promotions to attracted students (La, 2009; Al-Yousef, 2009).

\section{Formation and Evaluation of Alternatives}

This stage plays an important role in career decision making process, depending on the abilities of a pupil. According to Hossler et al. (1998), each alternative conforms to purposes and consequences of decision. The number of alternatives determines the complexity of the decision. Alternatives of some decisions are obvious while the origin of others is immediately clear. Another characteristic of the alternatives of the decision is how clearly formulated they are in the beginning of decision making process. Besides, other factors such as, value of career in the future (Moogan, 2003); physical distance from a living place to university or schools (Drewes, Michael 2006), finance for studying (Saichaie, Morphew, 2014).

Review indicates that recently Vietnamese students' 
feelings of self-efficacy were strongly associated with their occupational expectations and interests. Students' beliefs and values and their academic progress based on their self-reported grade point averages showed that these factors play important roles in their educational and career decision-making (Hoang, 2001; La, 2009; Ngo, 2005). However, in reality there are two main factors such as academic performance and finance issues strongly affect their choices of career even though students have strong belief in their own interest and value of career.

\section{Choice.}

Choice is defined in research literature as deciding to select one or more institutions and enrollment in a certain program of study, as well as vocational technique or journey to high school and university. The final decision regarding a particular program of study depends on the time spent in collecting information about the future studies and the possible alternatives. Many professional counselors, such as career consultants, teachers, representatives of colleges, members of admissions committees, consult and advise the prospective students in the process of searching and choosing a particular field of study. Kern (2000) remark that majority of pupils need these counselors in their secondary school to choose their career pathways.

In Vietnam, the choice of secondary school pupils takes place in class 9, most of them opt for high school as mentioned above (Khuat, 1992; Ngo 2005; La, 2009). Recently, there has been a change in the trend with the support from policies to promote development of vocational and technical education and orientation in both middle and high schools. Teachers and administrators are playing an important role in advising and helping students to get access to information about vocational and regular higher education programs. However, the result of these changes need more interest in research to show more clear evidences.

\section{EXPERIENCES \&DISCUSSION}

Currently, some studies found that with passage of each day, there has been an enormous change with having more students to confidently choose technical or vocational education of their career choice. For example, some students observed that the Traditional High School Education is not linked to their life goals and interest. Where high school mainly prefer theories and lacks career skills while some student's self-interest is in technical skills only for their career development. Therefore, they prefer to choose enroll in VTE for their own career interest and development (Dalton, 2018). With some of the students who have realized clear purpose of career decision and development by linking to long and short term goals since their secondary school, are confident to choose career path starting from their post-secondary planning experiences through their present enrollment in a technical post-secondary program (Dalton, 2018; Kight, 2015). Reviews indicated that the secondary's curriculum for career ready is significant impact on students who made decision to select technical or vocational education (Lamb, Arceneaux, Cox-Moses, Sweat \& Owens, 2013). The literature shows that secondary schools offer more courses teaching work based competencies, distribute employability skills lessons across all subject areas, and include technical and general skills. This will help students to enhance their career preparedness in order to make right decision (Guy et al., 2009). Darling et al. (2014), found that the incorporation between college or technical education and the work ready skills into secondary curricula make do not the students see the value of vocational education outcomes. Especially, students prefer technical skills, they do not pay attention to in a speech in the lessons of curriculum, they usually keen on visiting industry activities (Loera, Nakamoto, Oh \& Rueda, 2013).

In Vietnamese, secondary school prepare career ready for students through career orientation in grade 9, which comes at the end of class system. However, one emerge issue is lack of vocational guidance and counseling activities in secondary school in Vietnam (Nguyen, H. 2005). Another element which impacts students' career choice is a change in the structure of exams, Vietnam. In 2009, La stated that universities entrance exam was the main challenge for students, however, crossing this barrier becomes easy for students when Government extends the number of universities in Vietnam. In every province, there should be at least one local university which opens their doors to welcome students who are not much concern about their academic abilities (Loan, 2016). Therefore, Vietnamese secondary schools need to improve their task of career ready program with wise strategies. In which secondary schools need to provide fulfill information related to individuals interest, abilities, family context, developmental social-economic trends etc.(Loan et al, 2016).

Related to career preparation in secondary schools, reviews show that schools are usually facing some barriers, such as building self-efficacy for career development to post-secondary preparation created by schools that lack career consoler experiences. Lent and Brown (2000) argue that strong self-efficacy is key to students' perception of barriers to career achievement. They can build interventions to implement career counseling programs well before high school (Gibbons \& Borders, 2010). Another barrier is lack of orientation of technical education in career preparation program in secondary schools that result of student lack of information for career making decision (Nguyen, 2005).

Social Cognitive Career Theory (SCCT) highlights the temporal period which occurs in a particular environmental influence. Conceptual convenience and environmental variables are divided into two basic categories according to their relative proximity to career choice-making process. 
In order to overcome the challenges, one of the solutions is to apply Social Cognitive Career Theory (SCCT). This will help them develop their own framework for secondary school in order to prepare effective program of career ready (Dalton, 2018).

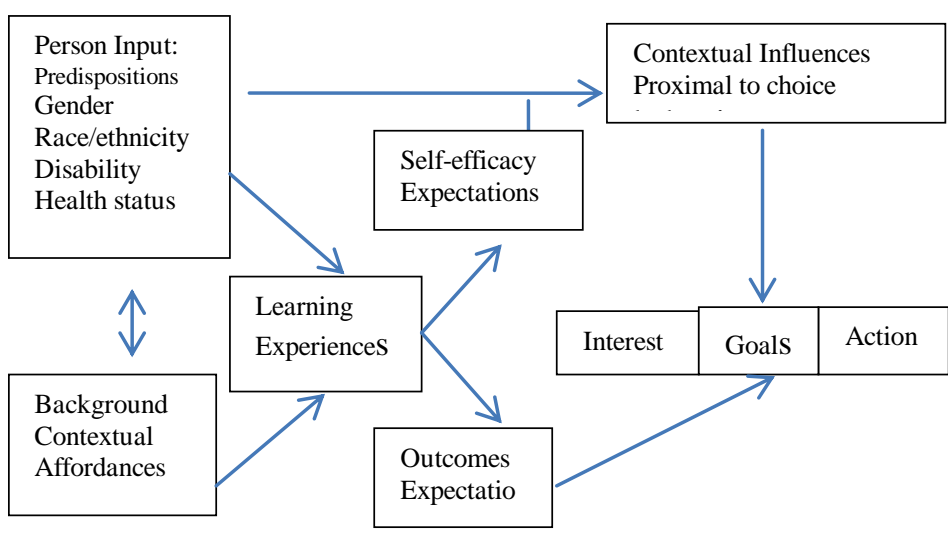

(Source: Lent, Brown \& Hackett, 1994)

Students need ample opportunities to develop their interests through career goal and activity selection, also to strengthen their self-efficacy in specific career interests (Brown \& Lent, 2013). Therefore, integrates of career orientation in lessons is a good way for students in secondary schools to improve self-efficacy in their own specific career interests.

Students' expectations and willingness is a strong factor to impact their career interests by setting new goals and selecting correlated skill building activities for strengthening self-efficacy (Brown \& Lent, 2013). Career interest plays a vital role and connect family with community expectations, socioeconomic status, and culture (Rojewski \& Kim, 2003; Thompson \& Dahling, 2012), educational expectations and experiences are significant contributing factors as well. To achieve the goal of producing career ready high school graduates, Grundman (2013) strongly suggested that schools must include career exploration, expectations and aspiration in daily lesson plans with school subject material and classroom curricula and should also connect school classwork to potential careers (Curry et al., 2013; Grundman, 2013; Wood \& Kaszubowksi, 2008). A notable thing, that is the level of strength of career interests from students' self-efficacy depend on the outcome of the career activities and goals they establish In which, contextual, personal, and experiential factors such as socioeconomic status, ability, cultural norms, and gender also affect students' access to career related behaviors (Brown \& Lent, 2013). Therefore, secondary schools should recognize their students' varying needs and deficiencies in career development process. They should be provided with career development resources and support for all students build self-efficacy that is one of the effective strategies (Praskova, Creed, \& Hood, 2015).
In secondary schools, career center as their best post-secondary preparation activity is supported to promote occupational engagement for student in career ready (Bennett, 2007).Technological educational courses are found to be effective in teaching career preparation skills and better prepare students for the post-secondary plans (Guy et al., 2009; Hanuscheck et al. 2011; Kim \& Passmore, 2016).

\section{v. CONCLUSION}

To sum up, the school-leaver's choice of studies process, four categories of influencing factors have been distinguished: educational factors (family: style of education; at school: recommendations of teachers and career counselors), professional educational system (quality of VTE training and employments; career transition); information factors (open days, exhibitions, mass media), economic factors (study fees, career prospects, incomes), other factors (geographical location of a higher education institution and ratings, personal skills and demography). Rowan-Kenyon (et al., 2011) inform that effective career developmental programs in secondary school are key in decision- making process and connect education to potential future careers for all students. Dalton, (2018) states that secondary schools need to integrate career exploration activities into the general curriculum and career developmental lessons. These strategies work to build student vocational identity, better inform students of the skills and demands of the workforce, and connect school work to future career skills. The core socio-cognitive variables of self-efficacy, outcome expectations and goals are defined in relation to career adaptive behaviors and their outcomes. The career exploration and skill building activities chosen by the participants were notably effective. Secondary and postsecondary technical education programs facilitate building self-efficacy and developing career interests, both important components of the career choice process. Building self-efficacy, supporting career interests, increasing career activities, understanding personal and contextual factors are factors that significantly impact on career development. This career decision making process and experiences apply SCCT in developing career ready program and the above analysis reviews expect to find a better way to improve career orientation for secondary school students in Vietnam.

\section{ACKNOWLEDGMENT}

The article of the study was conducted within the framework of the research project KHGD/16-20.ĐT.002 funded by the National Program on Science and Technology for the period 2016-2020 "Research and develop educational science to meet the requirements of fundamental and comprehensive renovation of Vietnamese education 


\section{Factors Influencing the Career Decision Making Process in Secondary School in Vietnam}

\section{REFERENCES}

1. Al-Fattal, A. (2010). Understanding student choice of university and marketing strategies in Syrian private higher education University. University of Leeds.

2. Al Yousef, H. (2009). 'They know nothing about university - neither of them went': The effect of parents' level of education on their involvement in their daughters' higher education choices. Compare: A Journal of Comparative and International Education, 39(6), 783-798.

3. Andrius, A \& Palmira (2013). Educational factors behind the success of rational decision making when entering university studies. Summary of Doctoral Dissertation Social Sciences, Educational Science (07S) 2015 , Kaunas

4. Bennett, D. (2009). Academy and the real world: Developing realistic notions of career in the performing arts. Arts and humanities in higher education, 8(3), 309-327.

5. Bottoms, G., Presson, A., \& Han, L. (2004). Linking Career/Technical Studies to Broader High School Reform: What Can School Districts, States and the Nation Do to Get More High Schools to Implement Comprehensive High School Reform? Research Brief. Challenge to Lead. Southern Regional Education Board.

6. Bruyat, C., \& Julien, P. A. (2001). Defining the field of research in entrepreneurship.

7. Briggs, S., \& Wilson, A. (2007). Which university? A study of the influence of cost and information factors on Scottish undergraduate choice. Journal of Higher Education Policy and Management, 29(1), 57-72.

8. Chak-keung Wong, S., \& Jing Liu, G. (2010). Will parental influences affect career choice? Evidence from hospitality and tourism management students in China. International Journal of Contemporary Hospitality Management, 22(1), 82-102.

9. Chimanikire, P., Mut, E., Gadzirayi, C. T., Muzondo, N., \& Mut, B. (2007). Factors affecting job satisfaction among academic professionals in tertiary institutions in Zimbabwe. African Journal of Business Management, 1(6), 166-175

10. Lent, R. W., \& Brown, S. D. (2013). Social cognitive model of career self-management: Toward a unifying view of adaptive career behavior

11. Lent, R. W., Brown, S. D., \& Hackett, G. (2000). Contextual supports and barriers to career choice: A social cognitive analysis. Journal of counseling psychology, 47(1), 36- 49.

12. Cosser, M., \& Du Toit, J. (2002). From school to higher education?: Factors affecting the choices of grade 12 learners(Vol. 1). HSRC. Retrieved: http://repository.hsrc.ac.za/handle/20.500.11910/8946

13. Curry, J. R., Belser, C. T., \& Binns, I. C. (2013). Integrating postsecondary college and career options in the middle level curriculum: Middle level educators must find ways to integrate postsecondary education and career exploration throughout the curriculum. Middle School Journal, 44(3), 26-32.

14. Dalton, D. (2018). Post-Secondary Preparation Experiences of Students Enrolled in a Technical College (Doctoral dissertation, Northeastern University).

15. Drewes, T., \& Michael, C. (2006). How do students choose a university?: an analysis of applications to universities in Ontario, Canada. Research in Higher Education, 47(7), 781-800.

16. Darling-Hammond, L., Wilhoit, G., \& Pittenger, L. (2014). Accountability for college and career readiness: Developing a new paradigm. education policy analysis archives, 22, 86 .

17. Eidimtas, A., \& Juceviciene, P. (2014). Factors influencing school-leavers decision to enrol in higher education. Procedia-Social and Behavioral Sciences, 116, 3983-3988.

18. Fermin, B., \& Pope, M. (2003). The perceptions of college students postsecondary education. College and University, 78(4), 19-25.

19. Gibbons, M. M., \& Borders, L. D. (2010). Prospective first-generation college students: A social-cognitive perspective. The Career Development Quarterly, 58(3), 194-208.

20. Grundmann, O. (2013). Career Readiness: An Old Idea Revived?. Journal of College Science Teaching, 43(1), 8-9.

21. Guy, B. A., Sitlington, P. L., Larsen, M. D., \& Frank, A. R. (2009). What are high schools offering as preparation for employment?. Career Development for Exceptional Individuals, 32(1), 30-41.

22. Hanushek, E. A. (2011). The economic value of higher teacher quality. Economics of Education Review, 30(3), 466-479. across the life span. Journal of counseling psychology, 60(4), 557-568 regarding the factors most influential in their decision to attend

23. Hossler, D., Hu, S., \& Schmit, J. (1999). Predicting student sensitivity to tuition and financial aid. Journal of Student Financial Aid, 28(4), 17-33.

24. Hoang, V. N. (2001). Vocational and Technical Education and Training in Vietnam and Issues of School to Work Transition Paper presented at the 2001 KRIVET International Conference on Technical and Vocational Educational and Training, Korea.

25. Kern, C. W. K. (2000). College choice influences: Urban high school students respond. Community College Journal of Research \& Practice, 24(6), 487-494.

26. Khuat, T. H. (1992). Thái độ của các nhóm cư dân ở một vùng nông thôn đối với học vấn và nghề nghiệp của con cái. From a rural area: Parents' attitudes toward their children's education and career. Diến đàn xã họi học tập, Tạp chí xã hội học số 1(37). Sociology forum. Journal of Sociology, 1(37).

27. Kim, K. N., \& Passmore, D. L. (2016). The benefits of high school experiences on growth in occupational status in US. International Journal for Educational and Vocational Guidance, 16(1), 113-136.

28. Knight, J. L. (2015). Preparing elementary school counselors to promote career development:Recommendations for school counselor education programs. Journal of Career Development (Sage Publications Inc.), 42(2), 75-85.

29. Lamb, T., Arceneaux, K., Cox-Moses, L., Sweat, T., \& Owens Jr., E. (2013). Examining factors that impact african-american ninth grade male students enrollment in math and science college preparatory courses. Journal of Technology Integration in the Classroom, 5(1), 55-62.

30. Lanero, A., Vázquez, J. L., \& Aza, C. L. (2016). Social cognitive determinants of entrepreneurial career choice in university students. International Small Business Journal, 34(8), 1053-1075.

31. Lent, R. W., Brown, S. D., \& Hackett, G. (2000). Contextual supports and barriers to career choice: A social cognitive analysis. Journal of counseling psychology, 47(1), 36-49.

32. Loera, G., Nakamoto, J., Oh, Y. J., \& Rueda, R. (2013). Factors that promote motivation and academic engagement in a career technical education context. Career and Technical Education Research,38(3), 173-190.

33. Lent, R. W., \& Brown, S. D. (2013). Social cognitive model of career self-management: Toward a unifying view of adaptive career behavior across the life span. Journal of counseling psychology, 60(4), 557.

34. Liguori, E. W., Bendickson, J. S., \& McDowell, W. C. (2018). Revisiting entrepreneurial intentions: a social cognitive career theory approach. International Entrepreneurship and Management Journal, 14(1), 67-78.

35. Lan, H. (2007 ). Chương trình phân ban phá sản? Retrieved August 18 , 2006

36. Loan, B. T. D \& Van N. T. (2015). Career guidance in Secondary school A literature review and Strategic solutions for Vietnamese Rural Areas, 4(5), 135-143.

37. McMahon, M., \& Watson, M. (2008). Introduction to the special section: Children's career development: Status quo and future directions. The Career Development Quarterly, 57(1), 4.

38. Moogan, Y. J., \& Baron, S. (2003). An analysis of student characteristics within the student decision making process. Journal of further and Higher Education, 27(3), 271-287.

39. Ngo, Q. P. (2005). Các quyết định luận phía sau hành vi hướng nghiệp của người đi học và lao động tìm kiếm việc làm. Paper presented at the Kỷ yếu hội thảo Pháp - Á: Vấn đề và hướng đi cho giáo dục hướng nghiệp tại Việt Nam, Hà Nội, Việt Nam.

40. Nguyen, D. T. (2005). Một số vấn đề về hướng nghiệp. Paper presented at the conference "Đối thoại và giải pháp: Vấn đề và hướng đi cho giáo dục hướng nghiệp Việt Nam”.

41. Nguyen, M. H. (2004). Sector development strategy-planning and priority program in Vietnam's socioeconomic development strategy to the year 2010, orientation toward the year 2020 and the system of guiding document, (compiled book on Goverment document ed.). Hanoi: Statistic Publisher.

42. Rowan-Kenyon, H. T., Perna, L. W., \& Swan, A. K. (2011). Structuring opportunity: The role of school context in shaping high school students' occupational aspirations. The Career Development Quarterly, 59(4), 330-344.

43. Rojewski, J. W., \& Kim, H. (2003). Career choice patterns and behavior of work-bound youth during early adolescence. Journal of Career Development, 30(2), 89-108. 
44. Saichaie, K., \& Morphew, C. C. (2014). What college and university websites reveal about the purposes of higher education. The Journal of higher education, 85(4), 499-530.

45. Shane, S., Locke, E. A., \& Collins, C. J. (2003). Entrepreneurial motivation. Human resource management review, 13(2), 257-279.

46. Shaver, K. G., \& Scott, L. R. (1992). Person, process, choice: The psychology of new venture creation. Entrepreneurship theory and practice, 16(2), 23-46.

47. Strauss, K., Griffin, M. A., \& Parker, S. K. (2012). Future work selves: How salient hoped-for identities motivate proactive career behaviors. Journal of applied psychology, 97(3), 580-598.

48. Taylor, J., Harris, M. B., \& Taylor, S. (2004). Parents have their say... about their college-age children's career decisions. Nace Journal, 64(2), $15-21$.

49. Thompson, M. N., \& Dahling, J. J. (2012). Perceived social status and learning experiences in social cognitive career theory. Journal of Vocational Behavior, 80(2), 351-361.

50. Wood, C., \& Kaszubowski, Y. (2008). The career development needs of rural elementary school students. The Elementary School Journal, 108(5), 431-444.

\section{AUTHORS PROFILE}

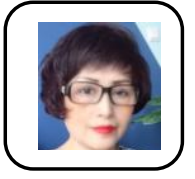

Do Thi Bich Loan is $\mathrm{PhD}$ in Educational Management, Associate Professor, and a senior researcher in Vietnam National Institute of Educational Sciences. She has over 20 years of experience in research of education policies and strategies, especially streaming and articulation in education system, as well as career guidance education issues of high school students. She has been publishing relevant papers in Vietnamese and international Journals. Currently, she is interested in solution to streaming students graduated from lower secondary school in the new context of lifelong learning development in Vietnam.

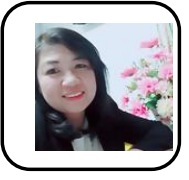

Nguyen Thuy Van had over 10 years' experience to her credit in teacher training and student development in a Vietnamese university and published relevant papers in Vietnamese Journals. Currently, she has been writing articles on academic advising, career development in Malaysian Public Universities. These articles are based on her $\mathrm{PhD}$ research journey of Educational management \& Administration in UTM (Universiti Teknologi Malaysia). Now, she especially enjoys preparing multi-culture crossing environment for student development in higher education.

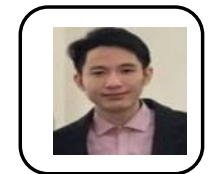

Nguyen Duc Trung is Master in architect, a researcher in The Institute for Research and Design of School, belong to Vietnam Ministry of Education and Training. He has more than 10 years of experience in research on facilities, school equipment, especially equipment for career guidance education of high school students. He has been publishing relevant papers in Vietnamese Journals. Currently, he is interested in school myopia issues due to the impact of facilities, teaching equipment and educational activities in high schools in Vietnam. 